\title{
The Effects of Research and Development (R\&D) Investments on Sustainable Economic Growth: Evidence from OECD Countries (1996-2015)
}

\author{
Şekip Yazgan, ${ }^{1}$ Ömer Yalçinkaya ${ }^{2}$
}

\begin{abstract}
This study is devoted to the empirical analysis by second generation panel data analysis of the effects of the R\&D investment variables in different qualifications in OECD countries grouped as OECD-20 and OECD-9 based on the income levels of the economic growth for the period of 1996-2015. Within this context, the purpose of this study is to evaluate whether or not the economic growth performances of OECD-20 and OECD-9 countries have a sustainable structure that endogenizes the technological advancements and occurs by the increments in average factor productivity. At the end of the paper it is determined that all the $R \& D$ variables in different qualifications of the OECD-20 group have a higher income level in sample period and have positive and statistically significant effects on the economic growth. On the other hand, only the private sector, universities and the total $R \& D$ investments have positive and statistically significant effects on the economic growth of the OECD-9 group which has comparatively lower income level. However, it is specified that the size of the positive and statistically significant effects of the R\&D investment variables in different qualifications is more than two times bigger in the OECD-20 group as opposed to the OECD-9 group. These results reveal that the economic performances of OECD-20 countries in the investigated period have a more substantial relation with the qualified and sustainable structure that endogenizes the technologic advancements and occurs by the increments in average factor productivity. All of this shows that the R\&D investments also are substantially sufficient to change the long-term economic growth performances and income levels of the countries in OECD-20 and OECD-9 groups.
\end{abstract}

Keywords: R\&D Investments, Technological Advancement, Sustainable Economic Growth, Endogenous Growth Theories, OECD Countries, Second Generation Panel Data Analysis.

Jel Classification: B22, C49, O32, O40.

Received: 12 April 2017 / Accepted: 6 November 2017 / Sent for Publication: 8 March 2018

\footnotetext{
${ }^{1}$ Department of Economics, Agri Ibrahim Çeçen University, Ağrı, Turkey. Corresponding author: Şekip Yazgan. sekipyazgan@ hotmail.com.

${ }_{2}^{2}$ Department of Economics, Agri Ibrahim Çeçen University, Ağrı, Turkey.

E-mail: omeryalcinkaya84@hotmail.com.
}

(C) 2018 by the authors; licensee Review of Economic Perspectives / Národohospodářský obzor, Masaryk University, Faculty of Economics and Administration, Brno, Czech Republic. This article is an open access article distributed under the terms and conditions of the Creative Commons Attribution 3.0 license, Attribution - Non Commercial - No Derivatives. 


\section{Introduction}

The concept of economic growth has been one of the most discussed and researched subjects in almost any period of economic life, and has played a significant role in all economic schools and in the evolution of economic thought. Economic growth relates an increase in production and capacity which are driven by two fundamental factors, such as the increase in the physical quantities of production factors per capita and / or the increase in average productivity of production factors based on technological developments when the institutional structure of the economy is taken into account. In this respect, these two factors are discussed as the main identifiers of economic growth in Classical, Keynesian, Neoclassical and Endogenous growth theories developed in an attempt to explain the reasons for economic growth and the differences in income (wealth) levels between countries.

Whereas in both Classical and Keynesian growth theory the economic growth process is explained by the increments in physical quantity of the production factors, the role of the increase in the average productivity of the production factors or the technological advancements are not considered. The effects of the technological development in the economic growth process were first introduced by J. A. Schumpeter (1939) within the evolution of economic thought. The essentials of Schumpeter's approach are based on the "long-way" theory of N. Kontradieff (1935) which statistically explains the financial expansion-shrinkage of capitalist economy at 50-60 year intervals. Schumpeter analyzes the effects of technological advancements on the economic growth systematically by associating the fluctuations in the capitalist economy to an invention-innovation bunch for each period (Türkcan, 2016: 54). He regards technological improvements as one of the primary identifiers of the economic growth and predicts a long-term and sustainable economic growth process differently from Classical or Keynesian growth theory (Akçomak, 2014: 477; Schumpeter, 1939: 83-84).

In Neo-Classical growth theories attributed to the work of Solow (1956) it is assumed that an economic growth process based on the accumulation of production factor is not only long-term but also technological developments balancing the diminishing returns on the basis of sustainable economic growth. However, Neo-classical growth theories mention that the technological advancements that allow for the increments in the average productivity of production factors are exogenous, and that it cannot be explained which mechanisms generate the effects of the technological advancements in the economic growth process. In addition, another flaw of the Classical and Keynesian growth theories, which try to explain the economic growth process only by factor accumulation are insufficient to explain the economic growth and income differences between countries and the fact that the predictions of Neo-Classical growth models which are based on the assumption that the technology is external and fixed, are preparing the environment for the emergence of new growth theories in the literature (Berber, 2011: 143). Due to these new growth theories also called endogenous growth models, the economic growth and income level differences between the countries are explained by factor accumulation; while the average factor productivity emerged is based on the technological advancements. 
Through endogenous growth theories, the approaches attempt to explain the economic growth process by the factors within the model through the endogenization of the technological advancements substitute for the methods, and they try to clarify this process by the factors determined from the model as described by Solow. In endogenous growth theories it is indicated that the most fundamental factor is the technological advancement based on the research and development (R\&D) investments for the explanation of the economic growth process, while several facts are revealed to account for this process by endogenous mechanisms. According to endogenous growth theories, the technological improvements emerge as a result of R\&D investments and increase the average productivity of the production factors, allow for being enhanced the economic growth qualitatively and made sustainable (Kibritçioğlu, 1998: 210). Within the context of endogenous growth models, the theoretical literature that researches the effects of the R\&D investments on the economic growth starts with the work of Romer (1986), where R\&D investments are seen as a fundamental fact of the economic growth process and are included into the model as endogenous. Romer (1986) assumes that knowledge of the source of endogenous growth. He also states that the society enhances the knowledge accumulation and that the economic growth increases the R\&D investments via savings, which finally lead to an interaction between the investments and the economic development. In this point, the growing effects of the R\&D investments in the economic growth process started being discussed with regards to the endogenous growth models. Such an analysis can be seen in the works of Grossman and Helpman (1991) or Aghion and Howitt (1992) who predicted the source of the endogenous growth effects on the productive investments in R\&D field.

Nowadays, it is general accepted that the economic growth feeds on basic sources as the increase the physical amounts of the production factors and the average productivities based on the technological advancement, the growth path provided by the provinces from these sources, is relatively easy but not sustainable in the long term. Thus, it is frequently expressed in economic literature that any growth process which is not based on human capital equipped by qualified education, the technology level developed by the R\&D investments and being improved the corporate structure operates the economy effectively, cannot be long term. In this respect, it is emphasized in recent studies that the two major factors that actualize sustainable and permanent economic growth in the long term are technological advancement and R\&D investments (TÜRKONFED, 2013: 16).

From this point of view, in this study, the effects of R\&D investments of different qualities (represented by the variables of $R \& D$ investments in public sector, private sector and universities; total R\&D investments; staff numbers working in R\&D sectors in OECD countries) classified according to their economic wealth levels on the economic growth, are empirically analyzed for the period of 1996-2015 on an annual basis. This paper econometrically evaluates the effects of $R \& D$ investments of different qualities and comments on the difference in economic performance and/or income levels of the countries in OECD-20 and OECD-9 groups within the investigation period. We believe that the findings of the study, conducted using comprehensive $R \& D$ investment variables and considering income level differences between OECD countries, is a positive contribution to the literature which has only had a limited number of works dealing with this subject. 
In the second chapter following the introduction, the empirical literature reviews the impact of R\&D investments on economic growth and is summarized in general terms; also, the paper's place within the economic literature is established. The third chapter introduces the data set used in the research, and the scope of the study is clarified. In the fourth chapter, the long-term effects of $R \& D$ investments on economic growth are econometrically analyzed within the new generation panel data analysis methodology that considers the cross-section dependence. Finally, the study concludes with general assessments and political inferences.

\section{Empirical Literature}

The theoretical approaches examine the effects of R\&D investments on economic growth are analyzed using endogenous growth models developed based on R\&D investments, such as those from the second half of the 1980s. It is apparent from the empirical literature that some macroeconomic (at firm, sector or region level) and microeconomic (country and country groups) studies have been conducted within the scope of time, as well as some panel data analysis for different countries and country groups. While R\&D investments at firm, sector or regional level are used in the studies on behalf of R\&D investments in microeconomic level3, the variables of the share of $\mathrm{R} \& \mathrm{D}$ investments in gross domestic product and staff number work in R\&D field are used on behalf of R\&D investments on macroeconomic level. On the other hand, reviewing the relevant literature, it can be seen that in numerous microeconomic studies conducted on various countries and country groups within the time period, or that incorporate panel data analysis, are actualized on OECD member countries (Altın and Kaya (2009-Turkey) Kim (2011-South Korea), Yanyun and Mingqian (2004) 4 , (Samimi and Alerasoul (2009)5, Mehran and Reza (2011)6, Gyekye et al. (2012)7, Inekwe (2015)8, (Park (1995), Freire-Serén (1999), Bassanini and Scarpetta (2001), Sylwester (2001), Zachariadis (2004), Falk (2007), Özer and Çiftçi (2009), Saraç (2009), Güloğlu and Tekin (2012), Eid (2012), Gülmez and Yardımcıŏlu (2012), Özcan and Arı (2014), Altıntaş and Mercan (2015), Türedi (2016)).

The studies using time series or panel data analysis considering variables of $R \& D$ investment find positive and statistically significant effect on economic growth (Del Monte and Papagni (2003), Botazzi and Peri (2003), Akçomak and Ter Weel (2009), Piras et al., (2011), Park (1995), Freire-Serén (1999), Bassanini and Scarpetta (2001),

\footnotetext{
${ }^{3}$ See the works in this context: (Del Monte and Papagni (2003), Botazzi and Peri (2003), Akçomak and Ter Weel (2009), Piras et al., (2011)).

${ }^{4}$ See the in this study conducted on Southeast Asian countries: Yanyun and Mingqian (2004).

${ }^{5}$ See the countries in this study conducted on developing countries: Samimi and Alerasoul (2009).

${ }^{6}$ See the countries in this study conducted for underdeveloped countries and OECD member countries: Mehran and Reza (2011).

${ }^{7}$ See the countries in this study conducted for countries of Southeast Asia and Sub-Saharan Africa: Gyekye et al. (2012).

${ }^{8}$ See the countries in this study conducted for developing countries: Inekwe (2015).
} 
Zachariadis (2004), Yanyun and Mingqian (2004), Falk (2007), Özer and Çiftçi (2009), Saraç (2009), Altın and Kaya (2009-Türkiye) Kim (2011-Güney Kore), Mehran and Reza (2011), Güloğlu and Tekin (2012), Eid (2012), Gülmez and Yardımcıoğlu (2012), Gyekye et al. (2012), Özcan and Arı (2014), Altıntaş and Mercan (2015), Inekwe (2015), Türedi (2016)). Additionally, some of these studies emphasize that the variables used on behalf of R\&D investments have no effect on economic growth (Sylwester (2001), (Samimi and Alerasoul (2009)).

When the above-mentioned literature is analyzed as a whole, the results can confirm the theoretically significant connection between $R \& D$ investments and economic growth in the empirical studies search the effects of R\&D investments on the economic growth at microeconomic and macroeconomic level and also mostly conducted on OECD countries. Moreover, it is worth mentioning that the income level differences of OECD member countries are not considered in the empirical studies examining the effects of the variables used on behalf of $R \& D$ investments on the economic growth. In this paper, following the literature review, the effects of $R \& D$ investments on economic growth are examined from a comparative perspective while considering the income level differences of OECD member countries and using the variables of R\&D investment of different qualities (R\&D investments in public sector, private sector or universities; total $R \& D$ investments and staff numbers work in R\&D field). For those reasons, this study should present a positive contribution to the literature on this subject.

\section{Data and Scope of the Research}

In this research, the effects of R\&D investments on economic growth are analyzed using second generation panel data analysis methodology on annual basis and empirically for the period of 1996-2015. ${ }^{9} 29$ OECD countries where R\&D investment data are accessible are used in the analysis after being grouped as OECD-20 and OECD-9 according to their (economical) wealth levels to investigate the effects of R\&D investments on the economic growth more consistently. ${ }^{10}$ This grouping process is based on the data of World Bank; the basis year of 2011 and the values of Gross Domestic Product (GDP) per capita in 2015 calculated in the purchasing power parity are taken for references. The countries which have GDP above USD 30.000 are accepted as OECD-20; the nine countries that have GDP values under USD 30.000 are included in the analyses as OECD-9. ${ }^{11}$ The evaluation of the effects of the R\&D investments on long-term economic growth performance and the identification of

\footnotetext{
${ }^{9}$ The variables used on behalf of R\&D investments for some of the OECD countries could be obtained uninterruptedly in the period of 1996-2015. Due to this accessibility, this period is accepted as the investigated time.

${ }^{10}$ Since the data of R\&D investments can be obtained discontinuously from 2000 and on, Australia, Switzerland Luxembourg, Chile and New Zealand are removed from the scope of the research.

${ }^{11}$ The order of the countries in the OECD-20 group is based on the size of the value of GDP in 2015 as follows: Norway, Ireland, USA, Netherlands, Sweden, Austria, Denmark, Germany, Canada, Iceland, Belgium, Finland, UK, Japan, France, South Korea, Italy, Spain, Israel and Czech Republic. The order of the countries in the OECD-9 group based on the same factor goes as follows: Slovakia, Slovenia, Estonia, Portugal, Poland, Hungary, Greece, Turkey and Mexico.
} 
differences in the income levels of these country groups is analyzed in the paper from all angles. The variables and the sources used in the models predicted to review the effects of R\&D investments in different conditions for OECD-20 and OECD-9 groups on economic growth are described in Table 1.

Table 1: Definition of the Variables Used in Models

\begin{tabular}{|c|c|c|}
\hline \multicolumn{3}{|c|}{ Sampling Period: 1996-2015 } \\
\hline $\begin{array}{l}\text { Abridgment of The } \\
\text { Variables }\end{array}$ & Explanation of The Variables & Data Source of The Variables \\
\hline PCGDP & GDP Per Capita (2011-USD) & \multirow{2}{*}{$\begin{array}{l}\text { World Development Indicators } \\
\text { (The World Bank). }\end{array}$} \\
\hline PCRFCF & $\begin{array}{l}\text { Real Fixed Capital Investments-Per Capita } \\
\qquad(2010-\text { USD })\end{array}$ & \\
\hline EL & Employed Manpower & $\begin{array}{l}\text { Total Economy Database } \\
\text { (The Conference Board). }\end{array}$ \\
\hline PUBLICR\&D & Real R\&D Investments of The Public (2010-USD) & \multirow{5}{*}{$\begin{array}{c}\text { Organization for Economic } \\
\text { Cooperation and Development- } \\
\text { Statistics } \\
\text { (OECD-Stat). }\end{array}$} \\
\hline PIRIVATER\&D $_{\text {RIV }}$ & $\begin{array}{l}\text { Real R\&D Investments of The Private Sector } \\
\text { (2010-USD) }\end{array}$ & \\
\hline$U N I_{R \& D}$ & $\begin{array}{l}\text { Real R\&D Investments of The Universities } \\
\text { (2010-USD) }\end{array}$ & \\
\hline TOTALR\&D & Total Real R\&D Investments (2010-USD) & \\
\hline STAFF $R \& D$ & Total R\&D Staff & \\
\hline Explanation & \multicolumn{2}{|c|}{$\begin{array}{l}\text { All variables described in the table are used in the analyses with the numbers of } \\
\text { annual growth rate in the investigated period. PCGDP variable and all monetary } \\
\text { variables used on behalf of the R\&D investments are taken from the relevant data- } \\
\text { base and in purchasing power parity. The total real R\&D investments variable is } \\
\text { composed of the sum of the real R\&D investments actualized by public, private } \\
\text { sector and universities. The total R\&D personal variable consists of the sum of } \\
\text { investigator, technician and other support staff who are full-time employees. The } \\
\text { variables of PCRGFCF and EL are used as the values per capita, proportioning the } \\
\text { total population in mid-year taken from the same database. Since the R\&D invest- } \\
\text { ment variables used in the study are intermittent in several years in the investigated } \\
\text { period for Estonia, Sweden, Iceland, Mexico, Norway and Greece, these data are } \\
\text { included in the analysis through being estimated via Linear Method in EViews } 9.5 \\
\text { packaged software. However, the models designed in the study are also estimated } \\
\text { by the incomplete data of the R\&D investment variables of the countries in the } \\
\text { relevant years and the similar results are obtained for both groups of countries. }\end{array}$} \\
\hline
\end{tabular}


Since the effects of R\&D investments on economic growth are used together with the time period data of OECD countries, the paper examines these effects through panel data analysis, which should safely determine the relations between the periods. Moreover, due to the fact that the effects of the R\&D investments of OECD-20 and OECD-9 groups on economic growth are analyzed by $R \& D$ variables in different qualities, the alternative models are predicted to avoid the multicollinearity problem. The following equation shows the econometric models that will be estimated with control variables of physical and human capital accumulation to determine the longterm effects of R\&D investments on the economic growth in OECD groups: ${ }^{12}$

$$
\begin{aligned}
& \text { Model-1: } \text { PCGDP }_{i t}=\alpha_{\mathrm{it}}+\beta_{1} \text { PCRGFCF }_{i t}+\beta_{2} E_{i t}+\beta_{3} \text { PUBLIC }_{\mathrm{RD} i t}+u_{i t} \\
& \text { Model-2:PCGDP } i t=\alpha_{\mathrm{it}}+\beta_{1} \text { PCRGFCF }_{i t}+\beta_{2} E L_{i t}+\beta_{3} \text { PIRIVATE }_{\mathrm{RD} i t}+u_{i t} \\
& \text { Model-3:PCGDP } i t=\alpha_{\mathrm{it}}+\beta_{1} \text { PCRGFCF }_{i t}+\beta_{2} E L_{i t}+\beta_{3} U N I_{\mathrm{RD} i t}+u_{i t} \\
& \text { Model-4:PCGDP } i t=\alpha_{\mathrm{it}}+\beta_{1} P C R G F C F_{i t}+\beta_{2} E L_{i t}+\beta_{3} \text { TOTAL }_{\mathrm{RD} i t}+u_{i t} \\
& \text { Model-5:PCGDP } P_{i t}=\alpha_{\mathrm{it}}+\beta_{1} \text { PCRGFCF }_{i t}+\beta_{2} E L_{i t}+\beta_{3} \text { STAFF }_{\mathrm{RD} i t}+u_{i t}
\end{aligned}
$$

$(\alpha),(\beta),(u)$, (i) and (t) respectively represent in the models the constant parameter, slope parameters, residual values and the countries in the panel and the time. The models designed to determine the long-term effects of R\&D investments of OECD-20 and OECD-9 groups on economic growth are analyzed in five stages within the scope of new generation panel data analysis methodology. In the first stage, the cross-section dependence creates the panel in cointegration equations and variables used in models are examined by LM tests. Once the presence of a cross-section dependence is identified through variables and cointegration equations used in the models, the stability of series is analyzed with the second generation panel unit root tests considering the cross-section dependence. The probable long-term relations between the variables are reviewed by Westerlund Panel Cointegration tests after it is determined that all the variables used in models are stationary at the same level [I(1)]. In the fourth stage, the coefficients of the long-term cointegration relation found in the cointegration tests are estimated using the estimator by Mark et al., (2005) DSUR. The direction of the causality relations between the variables in the models is examined through Panel Causality Test by Dumitrescu and Hurlin (2012) in the fifth and final stage.

\footnotetext{
${ }^{12}$ Since the R\&D data for Austria (Model-1, 2, 3, 5) and Israel (Model-5) in the OECD-20 group, and Mexico (Model-5) and Greece (Model-1, 2, 3, 5) in the OECD-9 group cannot be obtained in sufficient detail, these models are predicted through the subtraction of the relevant countries. The Gauss 10.0, Stata 14.00 and EViews 9.5 econometrically packaged softwares are used to predict the models established in the study.
} 


\section{Econometric Methodology and Findings}

The steady state of the variables matters in panel data analysis and inconsistent test statistics values such as $\mathrm{t}, \mathrm{F}$ and $\mathrm{R}^{2}$ that can be obtained when being analyzed by nonstationary series. Hence, the steady state of the series needs to be reviewed to achieve consistent results and avoid the spurious regression in panel data studies (Tatoğlu, 2013:199). The unit root tests used for the determination of the stationarity of the panel data are separated into two - the first and the second generation - when there is a crosssection dependence (CSD) in the units creating the panel. It is assumed that the section units forming the series are independent of each other and interdependent respectively. Any shock that may occur in a section causes that the series affects all the units at an equal rate in the first generation panel unit root tests, while the same shock impacts all the units at different rates in second generation panel unit root tests. Under these circumstances, the first generation panel unit root tests (Levin et al., 2002; Im et al., 2003; Breitung 2005 et al., etc.) do not produce unbiased results in case of being the CSD between the units create the panel, and the second generation panel unit root tests allow for the use of CSD (Breuer et al., 2002; Pesaran 2007; Hadri and Kurozumi 2012; etc.). Therefore, the cross-section dependence in cointegration equation should be examined before it calculates the models in panel data studies, and the unit root tests and other consecutive tests need to be specified. The test may produce inconsistent and biased results if this condition is ignored.

Furthermore, the section and time dimension of the series must be considered together when CSD is researched in the panel data. The CD-LM $\mathrm{Ldj}_{\mathrm{j}}$ test developed by Pesaran et al., (2008) can be used when the time dimension of the series is bigger $(\mathrm{T}>\mathrm{N})$ or smaller $(\mathrm{T}<\mathrm{N})$ than the section dimension. This test is also used when the time dimension is equal $(\mathrm{T}=\mathrm{N})$ to the section dimension (Pesaran et al., 2008: 105-127). The presence of CSD in CD-LM $\mathrm{Ldj}_{\text {adj }}$ test is investigated via the alternative hypothesis $\mathrm{H}_{1}$, which states that "there is a cross-section dependence in theories or the model", as opposed to the primary hypothesis $\mathrm{H}_{0}$, which says that "there is not a cross-section dependence neither in the series nor the model." The presence of a cross-section dependence in the series or the model is accepted if the null hypothesis is rejected in CD-LM $\mathrm{Ldj}_{\text {adj }}$ test that is considered on show asymptotically standard normal distribution. CD-LM $\mathrm{Ldj}_{\text {aj }}$ test analyzes the presence of CSD in cointegration equations of models and the series in models defined for OECD groups; Table 2 shows the results.

Evaluating the results in Table 2 in terms of the OECD groups, it can be observed that the probability values of $\mathrm{CD}-\mathrm{LM}_{\mathrm{adj}}$ test statistics calculated for the cointegration equations of the models and all variables in defined models are lower than 0.05. This means that the primary hypotheses created for variables in OECD groups and the cointegration equations based on the $\mathrm{CD}-\mathrm{LM}_{\mathrm{adj}}$ tests should be denied, and the alternative hypotheses should be accepted. These results confirm the presence of a cross-section dependence in the cointegration equations, and the variables in the models designed between the cross-section units create the panel in OECD-20 and OECD-9 countries. Moreover, the necessity of using the test methods of second generation panel data methodology for the next stages of empirical analysis indicate the presence of CSD. 
Table 2: Results of Cross Section Dependence (CSD) Test

\begin{tabular}{|c|c|c|c|c|c|c|c|}
\hline & & \multicolumn{3}{|c|}{ OECD-20 } & \multicolumn{3}{|c|}{ OECD-9 } \\
\hline \multicolumn{2}{|r|}{ Variables } & $\begin{array}{c}\text { CD-LMadj Test } \\
\text { Statistics }\end{array}$ & $\mathrm{P}$ & $\mathrm{T}$ & $\begin{array}{l}\text { CD-LMadj Test } \\
\text { Statistics }\end{array}$ & $P$ & $\mathrm{~T}$ \\
\hline \multirow{6}{*}{ 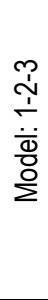 } & PCRGDP & $99.67^{*}[0.000]$ & 2 & 2 & $42.13^{*}[0.000]$ & 2 & 2 \\
\hline & PCRFCF & $97.95^{*}[0.000]$ & 2 & 2 & $31.65^{*}[0.000]$ & 3 & 2 \\
\hline & EL & $100.14^{*}[0.000]$ & 4 & 1 & $33.13^{\star}[0.000]$ & 3 & 1 \\
\hline & PUBLIC R\&D & $71.26^{*}[0.000]$ & 4 & 2 & $30.70^{*}[0.000]$ & 3 & 2 \\
\hline & PIRIVATE $_{R \& D}$ & $50.81^{*}[0.000]$ & 4 & 2 & $28.09^{*}[0.001]$ & 3 & 2 \\
\hline & UNIR\&D & $69.10^{*}[0.000]$ & 3 & 2 & $34.15^{\star}[0.000]$ & 3 & 2 \\
\hline \multirow{4}{*}{$\begin{array}{l}+ \\
\dot{\bar{\Phi}} \\
\dot{0} \\
\dot{\Sigma}\end{array}$} & PCRGDP & $104.99^{*}[0.000]$ & 2 & 2 & $61.19^{*}[0.000]$ & 2 & 1 \\
\hline & PCRFCF & $64.53^{*}[0.000]$ & 4 & 1 & $35.14^{*}[0.000]$ & 3 & 2 \\
\hline & EL & $111.95 *[0.000]$ & 2 & 1 & $50.03^{*}[0.000]$ & 2 & 1 \\
\hline & TOTALR\&D & $83.16^{*}[0.000]$ & 3 & 2 & $35.10 *[0.000]$ & 3 & 2 \\
\hline \multirow{4}{*}{$\begin{array}{l}\frac{10}{\bar{\phi}} \\
\frac{0}{2} \\
\frac{0}{2}\end{array}$} & PCRGDP & $93.78^{*}[0.000]$ & 2 & 2 & $39.59^{*}[0.000]$ & 2 & 1 \\
\hline & PCRFCF & $68.04^{*}[0.000]$ & 3 & 2 & $35.53^{*}[0.000]$ & 2 & 2 \\
\hline & EL & $52.78^{*}[0.000]$ & 4 & 1 & $27.33^{*}[0.002]$ & 3 & 1 \\
\hline & STAFF $_{R \& D}$ & $74.68^{*}[0.000]$ & 3 & 2 & $35.22^{\star}[0.000]$ & 3 & 2 \\
\hline \multicolumn{2}{|r|}{ Model-1 } & $7.58^{*}[0.000]$ & 3 & 2 & $2.14^{\star *}[0.016]$ & 3 & 2 \\
\hline \multicolumn{2}{|r|}{ Model-2 } & $8.19^{*}[0.000]$ & 3 & 2 & $2.13^{\star *}[0.017]$ & 3 & 2 \\
\hline \multicolumn{2}{|r|}{ Model-3 } & $9.04^{*}[0.000]$ & 3 & 2 & $2.12^{\star *}[0.017]$ & 3 & 2 \\
\hline \multicolumn{2}{|r|}{ Model-4 } & $9.95^{\star}[0.000]$ & 2 & 2 & $2.25^{\star *}[0.012]$ & 3 & 2 \\
\hline \multicolumn{2}{|r|}{ Model-5 } & $7.68^{*}[0.000]$ & 3 & 2 & $1.73^{\star *}[0.041]$ & 3 & 2 \\
\hline
\end{tabular}

Note: "*” and “**” before the CD-LMadj test statistics respectively indicate that there is a cross-section dependence in the series and the co-integration equations of models are at $1 \%$ and $5 \%$ significance grade. " $P$ " column in the table notifies the optimum lag lengths identified with the Schwarz information criteria for the variables and the co-integration equations. "2" on " $T$ ", column demonstrates that the relevant variable and the model are predicted in an intercept+trend form; "I" indicates that the relevant variable and the model are predicted in an intercept form. Source: authors' own estimation

The stationarity of the series in models established for the OECD groups is analyzed by Cross-Sectional ADF (Augmented Dickey-Fuller test) a second generation panel unit root test developed by Pesaran (2007) that considers cross-section dependence. In this test, first the $\mathrm{CADF}$ test statistics values are calculated for all cross-section units that make up the panel, and then the CIPS (Cross-Sectionally Augmented IPS Test) statistical data are obtained by using the arithmetic mean of these values for the panelwide. The CADF test statistics that can produce meaningful results also in cases of $\mathrm{N}<\mathrm{T}$ and $\mathrm{N}>\mathrm{T}$ are calculated in Equation 6: 


$$
t(N, T)=\frac{\Delta y_{i}^{\prime} \bar{M}_{i} y_{i-1}}{\bar{\sigma}^{2}\left(\Delta y_{i-1}^{\prime} \bar{M}_{i} y_{i-1}\right)^{1 / 2}}
$$

Next we calculated the CADF test statistics values, and obtained the CIPS statistics by averaging the values as follows:

CIPS $=N^{-1} \sum_{i=1}^{n} t(N, T)$

The CIPS test statistics values are compared with the critical table values obtained through Monte Carlo simulations by Pesaran, and the hypotheses for the stationarity are tested. As a result, the primary hypothesis $\mathrm{H}_{0}$ ("there is a unit root in the series") is rejected when the CADF and CIPS test statistics values are bigger than the critical table values, and the alternative hypothesis $\mathrm{H}_{1}$ ("there is not a unit root in the series") is accepted for the relevant unit panel-wide (Pesaran, 2007:265-312). The steady state of the series in the models created for the OECD groups is examined by the CIPS Panel Unit Root Test and Table 3 shows the results.

When the results in Table 3 are estimated by the OECD-20 and OECD-9 groups, it can be seen that the variables in the models are not stationary at the level value based on the $5 \%$ significance level. When the first differences of the variables are received, all variables in the models defined for the two country groups become stationary at 5\% significance level. This situation could be explained by the CIPS statistics values calculated in intercept+trend forms being bigger than the critical table values at 0.05 significance level and rejected the null hypotheses.

The difference-taking process of the series which become stationary at first differences, not the level, may destroy the effects of the short-term transitory shocks that have occurred in the past and any possible co-integrated relations in the long term. The stationary at first differences can be determined by using co-integration analyses whether the series are stationary or not (Tar1, 2010: 415). The first generation panel cointegration tests can produce consistent results in the models which do not have CSD (Johansen 1988; Kao 1999; etc.), whereas they may not produce unbiased results if the cross-section dependence is present. Consequently, the long-term relations between the variables need to be analyzed by the second generation panel co-integration tests, which accept a cross-section dependence (Westerlund 2008; Westerlund and Edgerton 2007; etc.). 
Table 3: Results of Panel Unit Root Test

\begin{tabular}{|c|c|c|c|c|c|c|c|c|c|}
\hline \multirow{2}{*}{\multicolumn{2}{|c|}{$\frac{\text { Panel-Wide (CIPS) Statistics }}{\text { Variables }}$}} & \multicolumn{4}{|c|}{ OECD-20 } & \multicolumn{4}{|c|}{ OECD-9 } \\
\hline & & \multirow{2}{*}{$\begin{array}{l}\text { Level } \\
-2.10 \\
\end{array}$} & $\begin{array}{c}\text { 1st } \\
\text { Difference }\end{array}$ & \multirow{2}{*}{$\begin{array}{l}P \\
2\end{array}$} & \multirow{2}{*}{$\begin{array}{l}T \\
2\end{array}$} & \multirow{2}{*}{$\begin{array}{l}\text { Level } \\
-1.78\end{array}$} & \multirow{2}{*}{$\begin{array}{l}\text { 1st Diffe- } \\
\text { rence }\end{array}$} & \multirow{2}{*}{$\begin{array}{l}P \\
2\end{array}$} & \multirow[b]{2}{*}{2} \\
\hline \multirow{6}{*}{ 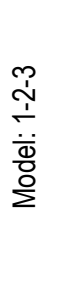 } & PCRGDP & & $-3.05^{\star}$ & & & & & & \\
\hline & PCRFCF & -2.22 & $-2.98^{*}$ & 2 & 2 & -2.64 & $-2.92^{*}$ & 3 & 2 \\
\hline & EL & -1.93 & $-2.76^{*}$ & 4 & 1 & -1.90 & $-3.22^{*}$ & 3 & 1 \\
\hline & PUBLIC & -1.89 & $-2.98^{*}$ & 4 & 2 & -2.41 & $-3.36^{*}$ & 3 & 2 \\
\hline & PIRIVATE $_{R \& D}$ & -2.49 & $-2.85^{\star *}$ & 4 & 2 & -2.22 & $-3.78^{*}$ & 3 & 2 \\
\hline & UNIR\&D & -2.58 & $-3.37^{*}$ & 3 & 2 & -2.42 & $-3.20^{*}$ & 3 & 2 \\
\hline \multirow{4}{*}{$\begin{array}{l}\stackrel{+}{\bar{\Phi}} \\
\frac{0}{2}\end{array}$} & PCRGDP & -2.05 & $-3.06^{*}$ & 2 & 2 & -2.15 & $-2.69^{*}$ & 2 & 1 \\
\hline & PCRFCF & -1.94 & $-2.85^{*}$ & 4 & 1 & -2.64 & $-3.09^{* *}$ & 3 & 2 \\
\hline & EL & -1.93 & $-2.82^{*}$ & 2 & 1 & -2.17 & $-2.49^{* *}$ & 2 & 1 \\
\hline & TOTALR\&D & -2.62 & $-2.98^{*}$ & 3 & 2 & -2.82 & $-3.02^{* *}$ & 3 & 2 \\
\hline \multirow{4}{*}{$\begin{array}{l}\frac{10}{\dot{\Phi}} \\
\frac{0}{2}\end{array}$} & PCRGDP & -2.12 & $-3.01^{*}$ & 2 & 2 & -1.96 & $-2.75^{\star}$ & 2 & 1 \\
\hline & PCRFCF & -2.00 & $-2.93^{*}$ & 3 & 2 & -2.44 & $-3.46^{*}$ & 2 & 2 \\
\hline & EL & -2.12 & $-2.65^{*}$ & 4 & 1 & -2.01 & $-4.84^{*}$ & 3 & 1 \\
\hline & STAFFR\&D & -1.65 & $-2.99^{*}$ & 3 & 2 & -2.51 & $-3.28^{*}$ & 3 & 2 \\
\hline \multirow{3}{*}{\multicolumn{2}{|c|}{ CIPS Critical Table Values }} & \multicolumn{2}{|c|}{-2.40} & -2.21 & 1 & \multicolumn{2}{|c|}{-2.60} & -2.34 & 1 \\
\hline & & \multicolumn{2}{|c|}{-2.92} & -2.73 & 2 & \multicolumn{2}{|c|}{-3.15} & -2.88 & 2 \\
\hline & & \multicolumn{2}{|c|}{$(\% 1)$} & (\% 5) & & \multicolumn{2}{|c|}{$(\%$ 1) } & $(\% 5)$ & \\
\hline
\end{tabular}

Note: “*” and “**” before the CIPS test statistics indicate that the series are stationary at $1 \%$ and 5\% significance grades respectively. The CIPS statistics critical table values are borrowed from Pesaran (2007) considering the conditions of $T$ and N. For " $P$ " and " $T$ " columns, see Table 2. Source: authors' own estimation

The Panel Co-Integration test by Westerlund and Edgerton (2007) is based on the Lagrange Multiplier test (LM) developed by McCoskey and Kao (1998) and uses Bootstrap method to allow for the correlation between the sections. In the test, the presence of long-term co-integration relations between the series is examined by the LM test statistics. The primary hypothesis $\mathrm{H}_{0}$ ("there is the co-integration relation between the cross-section series") is accepted at $1 \%$ significance level if the test statistics calculated based on the LM statistics are bigger than 2.33 critical table value, and the alternative hypothesis $\mathrm{H}_{1}$ ("there is not a co-integration relation between the crosssection series") is denied (Westerlund and Edgerton, 2007: 185-190). In this paper, the presence of long-term co-integration relations between the series in the models established for the OECD groups is analyzed through the Panel Co-Integration test by Westerlund-Edgerton (2007). Table 4 presents the results.

When the results in Table 4 are evaluated, it can be observed that the primary hypothesis in all defined models is accepted at $1 \%$ significance level. The LM test 
statistics values computed for models set higher than the critical table values (2.33) confirm this. These facts demonstrate that the variables in all models designed for the OECD-20 and OECD-9 groups have a tendency to follow similar trends in the long term. Homogeneous or heterogeneous status of the slope coefficients in the cointegration equation between the cross-section units can be assessed with Slope Homogeneity Tests by Pesaran and Yamagata (2008) after long-term relations between the series in all models designed for OECD-20 and OECD-9 groups are determined. In Slope Homogeneity Tests, the alternative hypothesis "the slope coefficients are not homogeneous" (as opposed to the primary hypothesis) is used to analyze whether the slope coefficients in co-integration relations differ with the cross-section units. The main hypothesis is confirmed by $1 \%$ significance level if the probability values of $\left(\tilde{\Delta}_{a d j}\right)$ test statistics are higher than 0.01 , which would also lead to a conclusion that the cointegration coefficients between the units are homogeneous (Pesaran and Yamagata, 2008: 50-93). ( $\left.\tilde{\Delta}_{a d j}\right)$ test reviews the homogeneity of the slope coefficients in cointegration equations of models defined for the OECD groups; see Table 4 for the results. Examining Table 4 , it can be seen that the probability values of $\left(\tilde{\Delta}_{a d j}\right)$ test statistics calculated for the models are higher than 0.01 . This means that the intercept term and the slope coefficients are homogeneous between the units and the long-term co-integrated relations are valid panel-wide.

Table 4: Result of Panel Co-Integration Test

\begin{tabular}{|c|c|c|c|c|}
\hline & \multicolumn{2}{|c|}{ OECD-20 } & \multicolumn{2}{c|}{ OECD-9 } \\
\hline Test Statistics & LM & $\tilde{\Delta}_{a d j}$ & LM & $\tilde{\Delta}_{a d j}$ \\
\hline Model-1 & $14.77^{*}[0.917]$ & $0.241^{\mathrm{a}}[0.405]$ & $10.07^{*}[0.631]$ & $-0.166^{\mathrm{a}}[0.566]$ \\
\hline Model-2 & $13.87^{*}[0.937]$ & $0.265^{\mathrm{a}}[0.397]$ & $9.31^{*}[0.774]$ & $-0.053^{\mathrm{a}}[0.521]$ \\
\hline Model-3 & $14.72^{*}[0.911]$ & $0.366^{\mathrm{a}}[0.357]$ & $9.30^{*}[0.781]$ & $-0.170^{\mathrm{a}}[0.568]$ \\
\hline Model-4 & $16.99^{*}[0.563]$ & $-0.096^{\mathrm{a}}[0.538]$ & $9.93^{*}[0.649]$ & $0.007^{\mathrm{a}}[0.497]$ \\
\hline Model-5 & $16.51^{*}[0.550]$ & $0.269^{\mathrm{a}}[0.394]$ & $8.24^{*}[0.751]$ & $-0.216^{\mathrm{a}}[0.585]$ \\
\hline
\end{tabular}

Note: “*” before the LM test statistics obtained from intercept+trend form means that there is a co-integration relation between the variables in the model at $1 \%$ significance grade. "a" before the $\tilde{\Delta}_{\text {adj }}$ test statistics indicates that the slope coefficients belong to the co-integration equations in models and are homogeneous at 1\% significance grade. The values in square brackets '[ ]' indicate that the probability values belong to the test statistics. Source: authors' own estimation.

In order to determine the long-run coefficients, the cointegration analysis is used to specify among the variables in the models for OECD groups. Since there is CSD in the models, the extent of the long-term effects of the explanatory variables of models on the dependent variable should be determined by the estimators considering the cross-section dependence. For that reason, the estimator of Panel AMG (Augmented Mean Group) developed by Bond and Eberhardt (2009) is used to obtain long-term coefficients in the OECD groups panel-wide. These co-integration coefficients are computed by weighting the arithmetic means of the long-term co-integration coefficients of cross-section units. The estimator of Panel AMG considers the common factors and dynamic effects of variables and produces agreeable results even if an endogeneity problem occurs 
(Eberhardt and Bond, 2009: 1-3). In this study, the models designed to determine the long-term effects of the R\&D investments on the economic growth of OECD groups are assessed by the Panel AMG method; see Table 5 for the results.

Table 5: Long-Term Co-Integration Coefficients: Results of Panel AMG

\begin{tabular}{|c|c|c|c|c|}
\hline \multicolumn{5}{|c|}{ Dependent Variable: PCGDP } \\
\hline Models & \multicolumn{2}{|c|}{ OECD-20 } & \multicolumn{2}{|c|}{ OECD-9 } \\
\hline Model-1 & Coefficients & Standard Errors & Coefficients & Standard Errors \\
\hline PCRFCF & $0.186^{*}$ & $0.028[0.000]$ & $0.285^{*}$ & $0.038[0.000]$ \\
\hline EL & $0.748^{*}$ & $0.159[0.000]$ & 0.138 & $0.142[0.330]$ \\
\hline PUBLIC R\&D & $0.028^{* *}$ & $0.013[0.025]$ & 0.017 & $0.013[0.194]$ \\
\hline Model-2 & Coefficients & Standard Errors & Coefficients & Standard Errors \\
\hline PCRFCF & $0.176^{*}$ & $0.034[0.000]$ & $0.294^{*}$ & $0.034[0.000]$ \\
\hline EL & $0.584^{*}$ & $0.163[0.000]$ & 0.186 & $0.148[0.207]$ \\
\hline PIRIVATER\&D & $0.087^{*}$ & $0.022[0.000]$ & $0.032^{*}$ & $0.007[0.000]$ \\
\hline Model-3 & Coefficients & Standard Errors & Coefficients & Standard Errors \\
\hline PCRFCF & $0.158^{*}$ & $0.027[0.000]$ & $0.301^{*}$ & $0.032[0.000]$ \\
\hline $\mathrm{EL}$ & $0.805^{*}$ & $0.116[0.000]$ & 0.073 & $0.114[0.524]$ \\
\hline UNI R\&D & $0.086^{*}$ & $0.019[0.000]$ & $0.060^{*}$ & $0.012[0.000]$ \\
\hline Model-4 & Coefficients & Standard Errors & Coefficients & Standard Errors \\
\hline PCRFCF & $0.151^{*}$ & $0.028[0.000]$ & $0.279^{*}$ & $0.015[0.000]$ \\
\hline EL & $0.509^{*}$ & $0.149[0.001]$ & $0.363^{*}$ & $0.118[0.002]$ \\
\hline TOTALR\&D & $0.155^{*}$ & $0.029[0.000]$ & $0.059^{*}$ & $0.019[0.002]$ \\
\hline Model-5 & Coefficients & Standard Errors & Coefficients & Standard Errors \\
\hline PCRFCF & $0.172^{*}$ & $0.031[0.000]$ & $0.282^{*}$ & $0.039[0.000]$ \\
\hline EL & $0.523^{*}$ & $0.161[0.001]$ & 0.110 & $0.154[0.475]$ \\
\hline $\mathrm{STAFF}_{\mathrm{R} \& \mathrm{D}}$ & $0.138^{*}$ & $0.038[0.000]$ & 0.051 & $0.041[0.206]$ \\
\hline
\end{tabular}

When the results for the OECD-20 group in Table 5 are evaluated, it can be concluded that the coefficients PCRFCF, EL, PUBLIC R\&D $_{\text {, PIRIVATE }}$ R\&D UNI $_{R \& D}, T_{O T A L_{R \& D}}$ and $\mathrm{STAFF}_{\mathrm{R} \& \mathrm{D}}$ explanatory variables are positive and statistically significant at different significance levels in all models without an exception. These results reveal that the enhancements in physical and human capital accumulation, R\&D investments actualized by the public, the private sector and the universities, the sum of the R\&D investments and the staff works in R\&D all contribute to the economic growth being positive and statistically significant. As for the OECD-20 group, the results show that 
the extent of positive and statistically significant effects of the R\&D investments of different qualities on economic growth can be aligned as the sum of R\&D investments, R\&D staff, and R\&D investments of the private sector, universities and public sector.

When the results for the OECD-9 group in Table 5 are analyzed, it can be identified that the PCRFCF, PUBLIC $R \& D$, PIRIVATE $E_{R \& D}, U_{R I_{R}}, T_{\text {TOTAL }} \& D$ and STAFF $_{R \& D}$ explanatory variables are positive (except $\mathrm{PUBLIC}_{\mathrm{R} \& \mathrm{D}}, \mathrm{STAFF}_{\mathrm{R} \& \mathrm{D}}$ ) and statistically meaningful at $1 \%$ significance level in all models as expected. These results prove that the enhancements in physical capital accumulation, R\&D investments actualized by private sector and universities and the total of the $R \& D$ investments in the investigated period affect the economy positively and as statically significant. Moreover, we can see in the results that the $R \& D$ investments actualized by public sector and number of employees (although the coefficients are positive, they are statistically insignificant) in R\&D do not have a significant effect on economic growth. Additionally, the extent of positive and statistically significant effects of $R \& D$ investments of different quality on the economy can be aligned as universities and total and private sector $\mathrm{R} \& \mathrm{D}$ investments respectively. On the other hand, when the results for the EL variable in Table 5, it can be observed that the EL explanatory variable is positive in all models without an exception and that it is statistically insignificant (except Model-4). This condition suggests that the increase in number of employees does not have a significant effect on economic growth, and that the connection between the number of employees and the economic growth breaks off when the education level is taken for the data.

In the models defined for the OECD groups, the aspect of the relations between the variables can be analyzed by causality tests once the long-term effects of $R \& D$ investments on economic growth are determined. In this paper, the direction of the longterm causality relations between the variables of $R \& D$ investments and the economic growth is examined with the Panel Causality Tests by Dumitrescu and Hurlin (2012) that considers cross-section dependence. The test takes into consideration the homogeneity and heterogeneity of the cross-sections and can produce consistent results for unbalanced panels as well. It analyzes the causality relations between the variables via $\left(Z_{N, T}^{H N C}\right)$ and $\left(Z_{N}^{H N C}\right)$ test statistics by considering the time and the cross-section dimension of the panel. $\left(Z_{N, T}^{H N C}\right)$ test statistic produces reliable results if the time dimension of the panel is bigger than the cross-section dimension $\left(Z_{N}^{H N C}\right)$ test statistic produces more consistent results if the time dimension is smaller than the cross-section dimension of the panel. The null hypothesis "there is not a causality relation between the variables in all cross section units" is rejected at 5\% significance level and the alternative hypothesis is accepted when the probability values of $\left(Z_{N, T}^{H N C}\right)$ and $\left(Z_{N}^{H N C}\right)$ test statistics calculated by Monte Carlo simulations are lower than 0.05 (Dumitrescu and Hurlin, 2012: 1450-60). This proves that there are causality relations between the series in at least some of the cross section units creating the panel. Dumitrescu and Hurlin's $\left(Z_{N, T}^{H N C}\right)$ test statistics review the causality relations between the variables of R\&D investments and economic growth; see Table 6 for the results. 
Table 6: Results of the Dumitrescu-Hurlin's Panel Causality Test

\begin{tabular}{|c|c|c|c|c|c|c|}
\hline & OECD-20 & \multicolumn{2}{|l|}{ OECD-9 } & OECD-20 & \multicolumn{2}{|l|}{ OECD-9 } \\
\hline Test Statistics & \multicolumn{2}{|c|}{$P C G D P \rightarrow P U B L I C_{R \& D}$} & $P$ & \multicolumn{2}{|c|}{ PUBLIC R\&D $\rightarrow$ PCGDP } & $P$ \\
\hline \multirow{2}{*}{$Z_{N, T}^{H N C}$} & $1.80^{\star * *}[0.072]$ & $-0.44[0.661]$ & 1 & $0.11[0.911]$ & $-0.71[0.456]$ & 1 \\
\hline & $5.86^{*}[0.000]$ & $1.01[0.314]$ & 2 & $1.47[0.141]$ & $-3.06^{*}[0.002]$ & 2 \\
\hline Test Statistics & \multicolumn{2}{|c|}{$\mathrm{PCGDP} \rightarrow \mathrm{PIRIVATE} \mathrm{E}_{\mathrm{R} \& \mathrm{D}}$} & $P$ & \multicolumn{2}{|c|}{ PIRIVATE $R \& D \rightarrow P C G D P$} & $P$ \\
\hline \multirow{2}{*}{$Z_{N, T}^{H N C}$} & $10.39^{*}[0.000]$ & $-0.51[0.615]$ & 1 & $-0.42[0.673]$ & $1.28[0.202]$ & 1 \\
\hline & $17.13^{*}[0.000]$ & $5.71^{*}[0.000]$ & 2 & $2.24^{* *}[0.025]$ & $5.26^{*}[0.000]$ & 2 \\
\hline Test Statistics & \multicolumn{2}{|c|}{$\mathrm{PCGDP} \rightarrow U \mathrm{UNI} I_{R \& D}$} & $P$ & \multicolumn{2}{|c|}{$\mathrm{UNI}_{R \& D} \rightarrow \mathrm{PCGDP}$} & $P$ \\
\hline \multirow{2}{*}{$Z_{N, T}^{H N C}$} & $2.11^{* *}[0.035]$ & $1.22[0.225]$ & 1 & $0.61[0.545]$ & $-0.78[0.437]$ & 1 \\
\hline & $17.08^{*}[0.000]$ & $5.79^{*}[0.000]$ & 2 & $1.59[0.112]$ & $-3.59^{*}[0.000]$ & 2 \\
\hline Test Statistics & \multicolumn{2}{|c|}{ PCGDP $\rightarrow$ TOTALR\&D } & $P$ & \multicolumn{2}{|c|}{ TOTALR\&D $\rightarrow$ PCGDP } & $P$ \\
\hline \multirow{2}{*}{$Z_{N, T}^{H N C}$} & $9.03^{*}[0.000]$ & $-0.04[0.965]$ & 1 & $-0.43[0.669]$ & $-0.30[0.763]$ & 1 \\
\hline & $14.02^{*}[0.000]$ & $5.38^{*}[0.000]$ & 2 & $3.96^{*}[0.000]$ & $0.61[0.541]$ & 2 \\
\hline Test Statistics & \multicolumn{2}{|c|}{$\mathrm{PCGDP} \rightarrow \mathrm{STAFF}_{\mathrm{R} \& \mathrm{D}}$} & $P$ & \multicolumn{2}{|c|}{$\mathrm{STAFF}_{\mathrm{R} \& \mathrm{D}} \rightarrow \mathrm{PCGDP}$} & $P$ \\
\hline \multirow{2}{*}{$Z_{N, T}^{H N C}$} & $2.62^{*}[0.009]$ & $1.59[0.266]$ & 1 & $4.03^{*}[0.000]$ & $0.46[0.646]$ & 1 \\
\hline & $6.43^{*}[0.000]$ & $2.14^{* *}[0.033]$ & 2 & $13.93^{*}[0.000]$ & $-0.33[0.744]$ & 2 \\
\hline
\end{tabular}

Note: “*”, “**” and “***” before the test statistics show that there is a causality relation between the series at 1\%, 5\%, and 10\% significance grades. The "P" column indicates the lag lengths, and the values in square brackets "[ ]" refer to the probabilities of the test statistics. Source: authors' own estimation.

When the 1-2 lagged results for the OECD-20 group in Table 6 are evaluated, it is apparent that there is a bidirectional causality relation between the private sector's total $R \& D$ investments and the number of employees in $R \& D$ with the economic growth. Furthermore, unidirectional causality relation between $R \& D$ investments of the public sector with universities and the economic growth and this relation moves from economic growth to the R\&D investments. When the 1-2 lagged results for the OECD-9 group in Table 6 are evaluated, a bidirectional causality relation is visible between the $\mathrm{R} \& \mathrm{D}$ investments of private sector with universities and the economic growth. A unidirectional relation between the R\&D investments of public sector and the economic growth and also unidirectional relation from economic growth to the R\&D investments. Additionally, the results in Table 6 indicate that there is a one-way causality relation between the total of R\&D investments and the number of employees in R\&D with the economic growth, and that it also moves from economic growth to the R\&D investments. The direction of the causality relations between the variables in the OECD20 and OECD-9 groups can be explained by the probability values that belong to the test statistics calculated for PCGDP, PUBLIC R\&D $_{2}$, PIRIVATE $_{R \& D}, U_{N_{R} \& D}, T_{O T A L_{R \& D}}$ and $\mathrm{STAFF}_{\mathrm{R} \& \mathrm{D}}$ variables being lower than $0.01,0.05$ or 0.10 . In line with the results of long-term Panel AMG in Table 5, all these results obtained from Dumitrescu and Hurlin's Panel Causality test reveal that the connection between the variables of R\&D 
investments and the economic growth is stronger in the OECD-20 group than the OECD-9 group.

\section{Conclusion}

In this study, the impact of R\&D investment variables of different quality in the OECD countries is empirically analyzed on an annual basis for the period of 1996-2015. 29 OECD countries are classified as OECD-20 or OECD-9 based on the wealth (income) levels to review the effects of $R \& D$ investments on economic growth. The purpose of the paper is to evaluate the effects of $R \& D$ investments on economic growth performances and differentiating income levels of OECD-20 and OECD-9 countries in every respect. The models designed using the control variables of physical-human capital accumulation (in order to analyze the long-term effects of R\&D investments on economic growth) are estimated within the scope of the second generation panel data methodology and take cross section dependence into account. As the final part of the paper, the results, which are compatible with the theoretical literature, are obtained with models constructed for the OECD-20 and OECD-9 groups. The findings can be summarized as follows:

It is determined that the effects of real fixed capital investments in all models defined for the OECD-20 and OECD-9 groups on the economic growth are positive and statistically significant. The extent of this positive effect is bigger in the OECD-9 group. Furthermore, it should be mentioned that when the education level functions as data in all of the models the effects of the employed on the economic growth are positive and statistically significant in the OECD-20 group, while the effects are positive and statistically insignificant in the OECD-9 group in general. Therefore, the connection between employed workforce and economic growth in the OECD-9 group, independently from the education level, is in comparison to the OECD-20 group poor.

On the other hand, the principal factors that change the effects on economic growth in the long term between two OECD groups are accepted as R\&D investment variables of different qualities used on behalf of innovation and technological advancement level of countries. Thus, the results of some of the models reveal that effects of all R\&D investments of different qualities on economic growth are positive and statistically significant. Moreover, according to the same results, the effects of R\&D investments of the private sector, universities and total $\mathrm{R} \& \mathrm{D}$ investments on economic growth are positive and statistically significant in the OECD-9 group, while the R\&D investments of the public sector and staff number work in the R\&D field do not have any effect on economic growth. These results suggest that all the variables used for the $R \& D$ investments in countries of the OECD-20 group and the variables of the R\&D investments in the private sector, universities and total R\&D investments in countries of the OECD-9 group are all predisposed to stimulate the economic growth. Moreover, the same results prove that the impact of $R \& D$ investments on economic growth is about twice as more pronounced in the OECD-20 group than in the OECD-9 group. This shows that there is a similarity between the OECD-20 and OECD-9 groups regarding the effects of R\&D investments of private sector and universities on the economic growth. However, a similarity cannot occur for the R\&D investments of public sector and staff numbers work in R\&D department. Additionally, the extent of the effects of 
R\&D investment variables of the OECD-20 and OECD-9 groups on the economic growth is confirmed in terms of the direction of the causality relations between the variables. In this direction the causality relation between $R \& D$ investment variables of different quality and the economic growth are stronger in the OECD-20 group.

To sum up, all these conclusions indicate that R\&D investments made separately by the public sector, private sector and universities and total R\&D investments that constitute the cumulative of these three sections in the OECD-20 group can be directed to innovative areas where they would create added value. The employment of staff in the $R \& D$ department can be economically effective as well. The results suggest that R\&D investments of the private sector and universities and the total R\&D investments in the OECD-9 group can some be directed to innovative areas to create added value, while the employment of staff in the R\&D department cannot be economically efficient. All these arguments reveal that the performance of economic growth of countries in the OECD-20 group during the investigated period is further based on qualified and sustainable structure actualized by the increments in average factor productivity by the endogenization of technological advancements.

Considering the reasons for classification of the countries in the OECD-20 and OECD-9 groups by their wealth levels, it should be mentioned that the R\&D investments of different qualities also are substantially important in differentiating of these countries in terms of the long-term economic growth performance or wealth levels (when all of the other conditions are stable). In this respect, the policy makers in the OECD-9 countries need to develop and apply long-term policies that would make the R\&D investments of public sector and R\&D staff quantitative/qualitative for increasing the information stock of the society. R\&D investments in the OECD-9 countries should be directed towards innovative areas to create added value via policy measures such as increasing the share of R\&D investments from the capital budget, improving the cooperation of public sector, private sector and universities, and investing more in human capital. Consequently, it would be possible to reduce the income level differences between the two country groups, strengthen the connections of R\&D investments and R\&D staff with economic growth, and also rise to the level of the OECD-20 group. Otherwise, the effects of the R\&D investments and staff of the R\&D department on the economic growth and the possible differences between the OECD-20 and OECD-9 group in income level would be similar in the future. If the required data are obtainable, further empirical studies on this subject can contribute to the improvement of the economic literature, for example by analyzing the country groups with definite development level differences.

Disclosure statement: No potential conflict of interests was reported by the authors. 


\section{References}

AGHION, P., HOWITT, P. (1992). A Model of Growth Through Creative Destruction. Econometrica, 60(2), 323351.

AKÇOMAK, I.S. (2014). Technology, Innovation and Economic Growth, in (Prepared by Ahmet Faruk Aysan-Devrim Dumludağ), New Approaches for Development, Imge 1st Edition, 473-493.

AKÇOMAK, S., TER WEEL, B. (2009). Social Capital, Innovation and Growth: Evidence from Europe. European Economic Review, 53 (5), 544-567. DOI: $\underline{10.1016 / j . e u r o e c o r e v .2008 .10 .001}$

ALTIN, O., KAYA, A. (2009). Analysis of the Casual Relationship Between R\&D Expenditures and Economic Growth for Turkey. Ege Academic Review, 9(1), 251-259.

ALTINTAŞ, H., MERCAN, M. (2015). R\&D Expenditures and Economic Growth Relation: Panel Cointegration Analysis under the Cross-Section Dependence on OECD Countries. Ankara University, Journal of Social Sciences Faculty, Volume 70, No 2, 345-376.

BASSANINI, A., SCARPETTA, S. (2001). The Driving Forces of Economic Growth: Panel Data Evidence for The OECD Countries. OECD Economic Studies, 33(2001/II), 9-56. <halshs00168383>

BERBER, M. (2011). Economic Growth and Development: Growth Theories and Development Economics, Trabzon: Derya Bookstore.

BOTAZZI, L., PERI, G. (2003). Innovation and Spillovers in Regions: Evidence from European Patent Data. European Economic Review, 47,687-710. DOI: 10.1016/S00142921(02)00307-0

BREITUNG, J. (2005). A Parametric Approach to The Estimation of Cointegration Vectors in Panel Data. Econometric Reviews, 24(2), 151-173. DOI: 10.1081/ETC200067895

BREUER, J. B., MCNOWN, R., WALLACE, M. (2002). Series- specific Unit Root Tests with Panel Data. Oxford Bulletin of Economics and Statistics, 64(5), 527-546. DOI: $\underline{10.1111 / 1468-0084.00276}$

DEL MONTE, A., PAPAGNI, E. (2003). R\&D and the Growth of Firms: Empirical Analysis of a Panel of Italian Firms. Research Policy, 32 (6), 1003-1014. DOI: S0048$\underline{7333(02) 00107-5}$

DUMITRESCU, E.I., HURLIN, C. (2012). Testing for Granger Non-Causality in Heterogenous Panels. Economic Modeling, 29(4), 1450-1460. DOI: 10.1016/j.econmod.2012.02.014

EBERHARDT, M., BOND, S. (2009). Cross-section Dependence in Nonstationary Panel Models: A Novel Estimator. Munich Personal RePEc Archive, MPRA Paper No: 17692. 
EID, A. (2012). Higher Education R\&D and Productivity Growth: An Empirical Study on High-Income OECD Countries. Education Economics, February, 20(1), 5368. DOI: $10.1080 / 09645291003726855$

FALK, M. (2007). R\&D Spending in the High-Tech Sector and Economic Growth. Research in Economics, 61, 140-147. DOI: 10.1016/j.rie.2007.05.002

FREIRE-SEREN, M.J. (1999). Aggregate R\&D Expenditure and Endogenous Economic Growth. UFAE and IAE Working Papers, No: WP 436.99

GROSSMAN, G., HELPMAN, E. (1991). Quality Ladders in the Theory of Economic Growth. Review of Economic Studies, 58, 43-61.

GULMEZ, A., YARDIMCIOĞLU, F. (2012). R\&D Expenditures and Economic Growth Relations in OECD Countries: Panel Cointegration and Panel Causality Analysis (1990-2010). Journal of Finance, 163, 335-353.

GÜLOĞLU, B., TEKIN, R.B. (2012). A Panel Causality Analysis of the Relationship Among Research and Development, Innovation, and Economic Growth In High-Income OECD Countries. Eurasian Economic Review, 2(1), 32-47.

GYEKYE, A. B., OSEIFUAH, E. K., QUARSHIE, V. (2012). The Impact of Research and Development on Socio-Economic Development: Perspectives from Selected Developing Economies. Journal of Emerging Trends in Economics and Management Sciences, 3 (6), 915-922.

HADRI, K., KUROZUMI, E. (2012). A Simple Panel Stationarity Test in the Presence of Serial Correlation and a Common Factor. Economics Letters, 115, 31-34. DOI: $\underline{10.1016 / j . e c o n l e t .2011 .11 .036}$

IM, K. S., PESARAN, M. H., SHIN, Y. (2003). Testing for Unit Roots in Heterogenous Panels. Journal of Econometrics, 115(1), 53-74. DOI: 10.1016/S0304-4076(03)00092-7

JOHANSEN, S. (1988). Statistical Analysis of Cointegration Vectors. Journal of Economic Dynamics and Control, 12(2), 231-254. DOI: 10.1016/0165-1889(88)90041$\underline{3}$

KAO, C. (1999). Spurious Regression and Residual-Based Tests for Cointegration in Panel Data. Journal of Econometrics, 90(1), 1-44. DOI: 10.1016/S0304$\underline{\text { 4076(98)00023-2 }}$

LEVIN, A., LIN, C. F., CHU, C. S. J. (2002). Unit Root Tests in Panel Data: Asymptotic and Finite-Sample Properties. Journal of Econometrics, 108 (1), 1-24. DOI: $10.1016 / \mathrm{S} 0304-4076(01) 00098-7$

INEKWE, J. N. (2015). The Contribution of R\&D Expenditure to Economic Growth in Developing Economies. Social indicators research,124.3: 727-745.

KIBRITÇIOĞLU, A. (1998). Economic Growth Determiners and Human Capital in New Growth Models. AU Journal of Political Sciences, 53(1-4), 207-230.

KIM, J.W. (2011). The Economic Growth Effect of R\&D Activity in Korea. Korea and the World Economy, 12(1),25-44. 
KONTRADIEFF, N. D. (1935). The Long Waves in Economic Life. The Review of Economic Statistics, 17(6): 105-115.

MCCOSKEY, S., KAO, C. (1998). A Residual-based Test of the Null of Cointegration in Panel Data. Econometric Reviews, 17, 57-84. DOI: 10.1080/07474939808800403

MEHRAN, M., REZA, M. (2011). A Comparative Investigation of the Relation of R\&D Expenditures to Economic Growth in a Group of the Less Developed Countries and OECD Countries. Journal of Social and Development Sciences, 2 (4), 188-195.

ÖZCAN, B., ARI, B. (2014). Research-Development Expenditures and Economic Growth Relation: Panel Data Analysis. Journal of Finance, 166, 39-55.

ÖZER, M., ÇIFTÇI, N. (2009). R\&D-Based Endogeneous Growth Models and the Effect of R\&D Expenditure on Economic Growth': OECD Countries Panel Data Analysis. SU Faculty of Economics and Administrative Sciences, Journal of Social and Economic Research, 219-239.

PARK, W.G. (1995). International R\&D Spillovers and OECD Economic Growth. Economic Inquiry, 33(4), 571-591. DOI: 10.1111/j.1465-7295.1995.tb01882.X

PESARAN, M. H. (2007). A Simple Panel Unit Root Test in The Presence of CrossSection Dependence. Journal of Applied Econometrics, 22(2), 265-312. DOI: $10.1002 /$ jae. 951

PESARAN, M. H., ULLAH, A. AND YAMAGATA, T. (2008). A Bias- Adjusted LM Test of Error Cross- Section Independence. The Econometrics Journal, 11(1), 105-127. DOI: $10.1111 / \mathrm{j} .1368-423 X .2007 .00227 . \mathrm{X}$

PESARAN, M. H., YAMAGATA, T. (2008). Testing Slope Homogeneity in Large Panels. Journal of Econometrics, 142(1): 50-93. DOI: 10.1016/j.jeconom.2007.05.010

PIRAS, G., POSTIGLIONE, P. AND AROCA, P. (2011). Specialization, R\&D and Productivity Growth: Evidence from EU Regions. The Annals of Regional Science, 49, 35-51. DOI: $10.1007 / \mathrm{s} 00168-010-0424-2$

ROMER, P.M. (1986). Increasing Returns and Long-Run Growth. Journal of Political Economy, 94(5), 1002-1037. DOI: $\underline{10.1086 / 261420}$

SAMIMI, A. J., ALERASOUL, M. S. (2009). R\&D and Economic Growth: New Evidence from Some Developing Countries. Australian Journal of Basic and Applied Sciences, 3 (4), 3464-3469.

SARAÇ, B. T. (2009). The Effect of Research\&Development Expenditures on Economic Growth: A Panel Data Analysis. Econ Anatolia 2009: Anadolu International Conference in Economics, 17-19 June 2009, Eskişehir, Turkey.

SCHUMPETER, J. A. (1939). Business Cycles: A Theoretical, Historical, and Statistical Analysis of the Capitalist Process, New York and London: McGraw-Hill.

SOLOW, R.M. (1956). A Contribution to the Theory of Economic Growth. Quarterly Journal of Economics, 70(1), 65-94. DOI: $10.2307 / 1884513$ 
SYLWESTER, K. (2001). R\&D and Economic Growth. Knowledge, Technology \& Policy, 13(4), 71-84.

TARI, R. (2010). Econometric, 6th Edition, Umuttepe Publishings, Kocaeli.

TATOĞLU, F. Y. (2013). Advanced Panel Data Analysis-Stata Applied, (2nd Edition), İstanbul: Beta.

TUREDI, S. (2016). The Relationship between R\&D Expenditures, Patent Applications and Growth: A Dynamic Panel Causality Analysis for OECD Countries. Anadolu Üniversitesi Sosyal Bilimler Dergisi, 16 (1), 39-48.

TURKCAN, E. (2016). Evolutionary Periods of Science and Technology in History, in (Prepared by İbrahim Semih Akçomak, Erkan Erdil- Mehmet Teoman Pamukçu-Murad Tiryakioğlu), Science, Technology and Innovation Concepts, Theories and Policy, Istanbul Bilgi University Publication 1. Bask1,47-60.

TURKONFED. (2013). Exit from Middle Income Trap, Which Turkey? Volume 2: Regional Development and Exit Strategies from the Dual Trap. (Prepared by E. Yeldan, K. Taşçı, E. Voyvoda, M. Emin Özsan), İstanbul: Turkish Enterprise and Business Confederation.

WESTERLUND, J. (2008). Panel Cointegration Tests of the Fisher Effect. Journal of Applied Econometrics, 23(2), 193-233. DOI: 10.1002/jae.967

WESTERLUND, J., EDGERTON, D. L. (2007). A Panel Bootstrap Cointegration Test. Economics Letters, 97(3), 185-190. DOI: 10.1016/j.econlet.2007.03.003

YANYUN, Z., MINGQIAN, Z. (2004). R\&D and Economic Growth-Panel Data Analysis in ASEAN+3 Countries. Seoul Conference 2004, Korea and the World Economy III.

ZACHARIADIS, M. (2004). R\&D-induced Growth in the OECD? Review of Development Economics, 8(3), 423-439. DOI: 10.1111/j.1467-9361.2004.00243.x 